УДК 811.133.1'373.422

ББК 81.471.1-315.4

DOI: https://doi.org/10.17308/lic.2020.1/2738

\title{
ЛЕКСИЧЕСКИЕ СРЕДСТВА ВЕРБАЛИЗАЦИИ АНТОНИМИЧЕСКИХ ОТНОШЕНИЙ В ТРИЛОГИИ ЭРВЕ БАЗЕНА «ЗМЕЯ В КУЛАКЕ»
}

\author{
О. Б. Полянчук, Е. И. Свиридова
}

Воронежский государственный университет

\section{LEXICAL MEANS OF ANTONYMIC RELATIONS VERBALIZATION IN TRYLOGY OF HERVÉ BAZIN'S NOVEL «VIPÈRE AU POING»}

\author{
O. B. Polyanchuk, E. I. Sviridova \\ Voronezh State University
}

\begin{abstract}
Аннотация: в статье рассматривается авторский концепт отрицания и особенности его объективации средствами антитезы, представленной антонимами различных видов. Демонстрация противопоставления двух элементов, их смысловое разграничение, а также их объединение определяются как основная функция антитезы, что становится опорой при построении антитетической когнитивной модели репрезентации противопоставления индивидуально-авторских художественных концептов. В иентре внимания находится кониепт-оппозиция «герой - внешний мир», являюшийся ключевым для раскрытия основных конфликтов романа Э. Базена «Змея в кулаке». Внутренний и внешний тип фокализации рассматриваются как важнейшее средство отражения отношений противопоставления, характер которого подчеркивается особенно ярко благодаря субъективной оценке от лица главного героя. Определяется ведущая роль фокализации при описании антонимических отношений, представленных антитезой. Изучается характер антонимических отношений, проводится их анализ с позиции теории внешней и внутренней фокализачии, а также определяется взаимосвязь контекстуальной и лингвистической антонимии. Источником исследования послужили три части трилогии, а объектом исследования-лексические средства вербализации основных противопоставлений трилогии.
\end{abstract}

Ключевые слова: концепт-оппозиция, художественный текст, внутренняя и внешняя фокализация, антонимия, антитеза, комплексный анализ, средства вербализации.

Abstract: the article discusses the author's concept of negation and its objectification features through the antithesis represented by antonyms of various forms. Demonstration of a binary opposition, the semantic distinction of antonyms, as well as their unification, are defined as the main function of antithesis which becomes the basis for antithetical cognitive model of representation of individual-authorial artistic concepts opposition creation. The focus is on H. Bazin's "Vipère au poing» and the concept-opposition "hero-external world", that is the key to uncover novel's main conflicts. Internal and external types of focalization are considered as the most important means of oppositional relationships reflecting, its character is emphasized most clearly by subjective assessment on behalf of the protagonist. The leading role of focalization in describing antonymic relations represented by the antithesis is determined. The nature of antonymic relations was studied, they were analyzed from the perspective of external and internal focalization, and the relationship between contextual and linguistic antonymy was determined. Antonymic relations character was studied and analyzed from a position of external and internal focalization. In addition, the interconnection between contextual and linguistic antonymy was determined. Three parts of the trilogy were investigated and lexical means of trilogy oppositions verbalization were emphasized.

Key words: concept-opposition, literary text, internal and external focalization, antonymy, antithesis, complex analysis, means of verbalization.

(C) Полянчук О. Б., Свиридова Е. И., 2020

Контент доступен под лицензией Creative Commons Attribution 4.0 License.

The content is available under Creative Commons Attribution 4.0 License. 
Настоящее исследование посвящено изучению особенностей объективации авторского концепта отрицания путем использования антитезы, представленной в тексте антонимами различных типов.

В современной лингвистике отмечается усиление исследовательского акцента на изучение индивидуально-авторских концептов. Этот может объясняться рядом причин: во-первых, набор культурных ценностей лимитирован, следовательно, концепты исчерпаемы; во-вторых, ранее изучались преимущественно ценности, разделяемые большинством носителей языка, а на периферии оставались индивидуальные ценностные ориентиры, авторские ценности - индивидуальные образы, которыми оперирует несреднестатистическая языковая личность [1, с. 119].

В любом художественном тексте возможно выделение текстовых концептов, объединенных личностным инвариантным смыслом, соответствующим миропониманию автора. Художественному тексту приписывается статус индивидуальной опосредованной картины мира. Термин «картина мира»в данном случае сопровождается уточнением «концептуальная» [2], а единицами картины мира признаются индивидуально-авторские концепты. Иными словами, картина мира - это основа художественного отражения действительности или художественной картины мира, фундаментом которой служат авторские взгляды и оценки как реального, так и моделируемого в тексте художественного мира, их развитие и влияние на содержание индивидуально-авторского концепта на разных этапах творчества. Под художественной (авторской) картиной мира вслед за М. М. Бахтиным мы понимаем специфическую форму мировосприятия, выступающую в качестве альтернативы реальному миру и представляющую собой результат внутренней работы автора, его творческой деятельности [3].

В художественных текстах часто представлены концепты, объединенные инвариантным личностным компонентом, который характеризует авторское видение действительности. Концепт не имеет обязательной связи со словом или другими языковыми средствами вербализации, его существование зависит от рационального отражения и осмысления, т. е. концепт возникает на базе личного опыта или путем соединения уже известных компонентов. Важно, что соединяться могут не только элементы действительности, но и признаки, не отражающие действительность. В реальности существуют такие признаки, как животное с копытами, животное с гривой и животное с рогом на голове, но эти признаки, объединенные в концепт «единорог», не являются отражением действительности по причине отсутствия в ней единорога [4].

Индивидуальная концепция мира писателя вербализуется рядом лексических средств, из которых стоит выделить оценочную лексику типа mieux (лучше) - mal (хуже), beau (красивый) - (некрасивый) и т. д. Говоря о средствах выражения авторского концепта, стоит уделить особое внимание средствам выразительности. Все, что окружает человека, может быть обозначено словом. Однако слова несут в себе не только информационную нагрузку о смысле явления или характере предмета. Благодаря средствам выражения, автор может преподнести конкретное явление или предмет в нехарактерном для него образе, создать для него соответствующую эстетическую, в частности негативную, окраску.

Когнитивный анализ художественного текста предполагает как выявление концептов, изучение способов их интеграции и построение фреймовых структур, так и исследование лингвистических средств их вербализации. Более того, одним из аспектов когнитивного анализа текста является изучение не только конкретного концепта, взятого обособленно, но и его оппозиции. В настоящем исследовании в центре внимания оказывается концепт-оппозиция «герой - внешний мир» и лингвистические (в частности, словообразовательные и семантические) средства его репрезентации. Концепт-оппозиция «герой - окружающий мир» определяет конфликт как движущую силу сюжета романа. На нем базируется раскрытие типологии языковой личности главного героя. Именно конфликт как воплощение борьбы противоположностей разделяет вселенную трилогии Эрве Базена «Семья Резо» на противоборствующие стороны [5].

Разделяя мысль С. В. Манджиевой о том, что концепты, представляемые в текстах художественных произведений, подвергаются влиянию авторского мировоззрения, получая специфический, индивидуальный ракурс [6, с. 5], мы хотели бы подчеркнуть, что специфика текста заключается в его целостности, т. е. в единстве языковых, речевых и когнитивных компонентов, взаимодействие которых определяет его смысловую составляющую. Подобная целостность, а также многообразие подходов к изучению текста, представляет не только простор методов исследования текста, но и оставляет проблемы интерпретации текста открытыми, что определило актуальность данного исследования.

Цель настоящего исследования заключается в определении средств вербализации антонимических отношений в трилогии Эрве Базена «Семья Резо» и их систематизации.

Исходя из цели, были определены следующие задачи данной работы: во-первых, изучить характер антонимических отношений на примере трилогии «Змея в кулаке», во-вторых, определить основные антитезы романа и провести их анализ с точки зрения авторского приема внешней и внутренней фокализа- 
ции, в-третьих, провести анализ лексики, характеризующей антитезы романа, осуществить ее классификацию, привести в соответствие типы лексической антонимии и выявленные типы концептов-оппозиций и, наконец, определить взаимосвязь контекстуальной и лингвистической антонимии.

Перед тем как перейти к решению поставленных задач, необходимо остановиться на актуальных для данного исследования теоретических положениях.

Вслед за Р. Бартом мы рассматриваем антитезу как фигуру, призванную разъединять, так как ее элементы разделены прочнейшим из барьеров - барьером смысла. Термин «барьер смысла» обозначает смысловое «препятствие» между компонентами антитезы, противопоставленными друг другу. Французский исследователь видит в антитезе «образ вражды» и сравнивает ее со «стеной без двери» [7, с. 79], подчеркивая семантическую несовместимость представляемых ею элементов. Но Р. Барт также отмечает, что антитеза дает возможность противоположностям соединиться, выступая в качестве трансгрессии, т. е. позволяя отличным друг от друга элементам слиться и стать единым целым [7, с. 39].

Характерной для человеческого сознания когнитивной моделью, наряду с прочими, является антитетическая модель восприятия действительности. По словам Ш. Балли, человеческий ум склонен постоянно противопоставлять друг другу различные понятия [8, p. 181]. Ф. Робгриё считает, что антитеза устанавливает отношения противопоставления между двумя мыслями, одна из которых делает значимой другую [9, р. 120]. Таким образом, антитеза оказывается сложным ментальным конструктом. Являясь фигурой мысли, антитеза реализуется, прежде всего, на ментальном уровне.

Р. Барт также считает, что антитеза может и объединять «несовместимое», и обеспечивать переход из крайности в крайность. Значит, основной функцией антитезы является не только демонстрация противопоставления двух элементов и их смысловое разграничение, но и их объединение. Это становится опорой при построении антитетической когнитивной модели репрезентации противопоставления индивидуально-авторских художественных концептов.

Ведущая роль человека в процессах восприятия и порождения речи диктует необходимость изучения языка с позиции индивидуального человеческого мышления. Антитеза, в основе которой лежит языковая антонимия, т. е. значение системного противопоставления, закрепленное в языке, однозначно воспринимается адресатом речи, в то время как контекстуальная антонимия воспринимается читателем лишь с учетом контекста и личного опыта, что делает процесс понимания более сложным с одной стороны и более специфичным с другой.
В художественном тексте мы отмечаем наличие как антитезы, носящей типовой характер, так и антитезы индивидуально-авторского характера, которая воспринимается не непосредственно, а через серию косвенных маркеров. Например, мы наблюдаем следующие проявления антитезы эксплицитного характера, выражающиеся в основных конфликтах, заключенных в художественном тексте: конфликт добра и зла, любви и ненависти, верности и предательства, мира и войны и т. д. Необходимо отметить, что в настоящем исследовании перечисленные концептыоппозиции рассматриваются в рамках макроконцепта-оппозиции «герой - внешний мир». На наш взгляд, индивидуально-авторская антитеза представляет наибольший интерес для изучения, так как, являясь по своей сути скрытой, она обнаруживает скрытые противопоставления, заложенные автором, а следовательно, имплицирует не только языковые противопоставления, но и индивидуальные, принадлежащие непосредственно автору, что дает ключ к пониманию авторского видения мира, т. е. авторского концепта и его влияния на содержание художественного текста и его восприятия читателем. Кроме того, средства вербализации концептов-оппозиций (т. е. типовых средств актуализации антитезы) могут быть представлены не только на лексическом уровне, но и на словообразовательном (что проявляется в высокой частотности употребления отрицательных приставок). Этот факт приводит к различной степени выраженности антитезы, что объясняется спецификой взаимодействия таких типов языковых значений, как словообразовательное и лексическое $[10 ; 11]$.

Мы рассматриваем художественный текст как результат мыслительной деятельности автора, представляющий собой лабиринт, наполненный подсказками в виде авторских приемов, служащих для восприятия идей и мыслей, скрытых в нем. Автор часто располагает идеи разной степени эксплицитности в иерархическом порядке. Более того, идеи автора не всегда реализуются в полной мере вербальными средствами. Автор вербализует разность, полученную в результате вычитания из собственного замысла предполагаемых знаний читателя. Читатель, в свою очередь, суммирует эту разность в соответствии с собственными знаниями. Через текст автор осуществляет процесс коммуникации с читателем, стремясь вызвать эмоциональный отклик. Воздействие на читателя определяется выбором определенных языковых средств, несущих в себе эффект экспрессивности и эмоциональности. Автор выбирает индивидуальные лексические, грамматические, синтаксические, стилистические и другие средства, призванные донести авторское видение мира [12].

Несправедливо было бы не указать на жанровую специфику исследуемой трилогии Э. Базена и не 
обратиться к исследованию Н. А. Литвиненко, в котором автор полагает, что «важно не абсолютизировать один инвариант литературного жанра, одну модификацию, а осмысливать специфику трансформации тематического начала, приобретающего или утрачивающего ту или иную жанровую функцию» [13]. Нам важно подчеркнуть, что в трилогии Базена черты семейного и исповедального романа смешаны, что позволяет прослеживать противоречия не только через внешний конфликт, но, в первую очередь, через внутренний мир героя. Таким образом, перед читателем предстает интимная сторона жизни главного героя, что делает его мотивацию ближе и понятнее. «Внутренний» и «внешний» планы повествования дают возможность автору разнопланово продемонстрировать среду, в которой развивается герой. Основная задача, в нашем случае, при подобной демонстрации возложена на внутрисемейный конфликт. Важнейшим значением обладает характер связи главного героя с другими членами семьи, взаимодействие представителей разных поколений, отличающихся своим образом мыслей и ценностными ориентирами. Семья рассматривается как сдерживающая и враждебная сила.

Через исповедь Э. Базен демонстрирует нарастание конфликта одновременно с нарастанием чувства ненависти, а затем переход к любви и прощению. Этот путь искупления связывает три части романа воедино: Жан Резо «побеждает» в войне с матерью благодаря своей ненависти, но затем осознает бесполезность победы, связывающей его с прошлым. Жан становится на путь поиска счастья, для прохождения которого ему необходимо преодолеть и переделать себя, ему предстоит обрести себя.

В связи с вышеизложенным особенно значительным для исследования оказывается организация повествования - выбор автором точки обзора, с которой демонстрируются описываемые события. В данном контексте необходимо обратиться к такому ключевому понятию, как «фокализация». Фокализация как подход к исследованию проблемы зрительной перспективы в литературных произведениях был заложен Жаном Пуйоном. Термин получил широкое распространение благодаря Жерару Женетту, который под фокализацией понимал организацию в повествовании точки зрения и способы донесения ее до читателя [14, c. 204]. Ж. Женетт также выделил типы фокализации:

- нулевая фокализация, при которой повествование ведется с точки зрения всеведущего автора. Рассказчик обладает более полной информацией, чем любой персонаж;

- внутренняя фокализация, когда повествование ведется от лица персонажа, т. е. рассказчик и персонаж обладают идентичным объемом информации, и таким образом, повествование становится субъективным;
- внешняя фокализация, при которой повествование ведется с точки зрения «объективного нарратора», знающего даже меньше, чем персонаж» [15, c. 41-42].

При более подробном рассмотрении каждого типа фокализации, мы, вслед за М. М. Бахтиным, выделяем следующие основные характеристики, присущие каждому типу. При нулевом типе фокализации отношение автора к персонажу становится тождественным отношению героя к себе. Мысли и чувства героя принадлежат автору, и он открыто демонстрирует их читателю. При внутренней фокализации читателю доступен взгляд на мир исключительно глазами персонажа. Читатель получает информацию искаженной через призму субъективного анализа героя, его индивидуальную интерпретацию событий. При внешнем типе фокализации герой «доминирует» над автором, взгляд на героя оформляется при помощи нейтрального, безоценочного нарратива [16, с. 15].

Таким образом, фокализация представляет собой средство моделирования смыслов на уровне организации текста. Противопоставление того, что видит персонаж и того, что рассказывает повествователь, может быть выражено на текстовом уровне различными средствами. Необходимо также указать, что для нашего исследования особый интерес представляет оценочная лексика как средство репрезентации ценностных ориентаций, представляющих как авторский концепт отрицания в целом, так и каждый микроконцепт-оппозицию в частности.

\section{Основные концепты-оппозиции романа \\ Э. Базена «Змея в кулаке»}

Изучая трилогию Эрве Базена «Змея в кулаке» с позиции теории фокализации, мы отметили преобладание внутренней фокализации, характеризующейся крайне субъективной оценкой событий главным героем трилогии. Повествование в трилогии ведется от лица главного героя Жана Резо, чья личность сопряжена с личностью автора, т. е. самого Э. Базена. Каждое событие трилогии, поведение каждого из героев, в том числе свое собственное, Жан Резо комментирует и поясняет в полном объеме, предоставляя читателю набор ассоциаций, подчеркивающих основные конфликты произведения, т. е. основные антитезы, с помощью которых автор выражает борьбу противоположных тенденций. Кругозор нарратора в романе базируется на интерференции двух перспектив. Повествование ведется в рамках одного мнения, а также с позиции времени - нарратора, корректирующего субъективное мнение героя. На протяжении всей трилогии мы наблюдаем идентичные конфликты, но, говоря о процессе вербализации индивидуально-авторского концепта, необходимо отметить специфику выражения антонимических 
отношений, которые могут нередко оказываться имплицитными.

В трилогии также отмечается факт наличия внешнего типа фокализации, отражающей «вечные» конфликты, выявленные в тексте, т. е. противопоставления, являющиеся общепринятыми и очевидными для читателя, воспринимаемые им обособленно от контекста. Однако внешний тип фокализации не является частотным.

Таким образом, внутренняя фокализация в трилогии Эрве Базена «Змея в кулаке» является важнейшим средством отражения антитетических отношений, характер которых подчеркивается особенно ярко благодаря субъективной оценке от лица главного героя. Так, после определения роли фокализации в выражении антитезы важно обратиться непосредственно к характеристике антонимических отношений, представленных антитезой, для дальнейшего определения основных лексических средств и вербализации основных конфликтов трилогии.

Переходя к практическим результатам исследования, отметим, что нами было исследовано три части трилогии: «Змея в кулаке», «Смерть лошадки», «Крик совы», содержащие около 49000 лексем, из которых были выделены лексические средства вербализации оппозиций трилогии.

В процессе исследования использовались следующие методы: концептуальный анализ, контекстуальный и компонентный анализ.

Трилогия Эрве Базена «Семья Резо» характеризуется наличием ярко выраженной антитезы, составляющей основу повествования. Сюжетные линии произведения содержат в своей основе противопоставление. Так, в процессе исследования были выделены основные конфликты трилогии, которые вписываются в общую «формулу» конфликта «герой - внешний мир». Главный герой Жан Резо противопоставлен своей матери. Мадам Резо, являясь собирательным образом семьи Резо и мира, в котором родился Жан, порождает ряд иных конфликтов, которые можно условно разделить на три группы: любовь - ненависть, свобода - несвобода, созидание - разрушение. Важно отметить, что данные противопоставления прослеживаются на всей протяженности повествования, что доказывает их ведущую роль в построении сюжета. Более того, помимо ключевого характера антитезы, факт постоянного наличия противопоставления отражает непрерывный характер антитезы и, как следствие, те перманентные характеристики событий и персонажей, которые отражают авторский контекст. Также при учете явления фокализации как основы для классификации сюжетных противопоставлений антитеза приобретает скрытый или явный характер, в зависимости от способа ее выражения в трилогии - с помощью внутренней или внешней фокализации соответственно.

Таким образом, антонимические отношения в трилогии Э. Базена, представленные антитезой, носят ключевой, непрерывный, явный или скрытый характер.

Исходя из особенностей построения сюжета и принимая во внимание основные интересующие автора концепты: любовь, свобода и разрушение, - мы пришли к выводу, что ведущая роль в трилогии принадлежит антонимическим отношениям, являющимся репрезентацией основной «глобальной» антитезы «герой - внешний мир», которая для точности и наглядности анализа была разделена на более конкретные противопоставления, такие как: «любовь - ненависть», «свобода - несвобода» и «разрушение - созидание».

Исследуемые противопоставления стали предметом изучения вследствие их ведущей роли в произведении, а также их основополагающей для демонстрации конфликтов персонажей роли. Выявленные антитезы были рассмотрены с точки зрения авторского приема внешней и внутренней фокализации, т. е. с субъективной позиции главного героя и с точки зрения «вечности», исторических событий и конфликтов, воспринимаемых читателем обособленно от контекста. Анализируемые лексемы были классифицированы на основе их парного или непарного употребления, а также на основе их прямого или косвенного отношения к ядру лексико-семантического поля антитезы.

Далее обратимся к каждой из выделенных антитез и рассмотрим подробнее особенности вербализации представляющих их концептов.

Одним из ключевых противопоставлений трилогии «Змея в кулаке» является противостояние любви и ненависти, на котором базируется главная сюжетная линия конфликта Жана Резо с матерью. Любовь и ненависть представлены автором как два противоположных пути, один из которых Жан должен избрать для дальнейшей жизни. Процесс выбора провоцирует внутренний конфликт героя с собственным «я», изменяющимся под воздействием окружающего мира и матери, а также открытую борьбу против навязываемого образа жизни и ценностей. Автор рассматривает данный конфликт с двух точек зрения. С помощью приема внешней и внутренней фокализации автор демонстрирует, как любовь и ненависть находят свое выражение в словах и поступках действующих лиц повествования, а также как оппозиция «любовь ненависть» представлена через призму субъективной оценки героями трилогии.

Так, при изучении антитезы «любовь - ненависть» с позиции внешней фокализации, было установлено, что данная антитеза представлена в тексте 
наиболее частотно, что позволяет охарактеризовать ее как ядерную антитезу трилогии, описывающую центральный конфликт. Нами были отобраны лингвистические антонимы и охарактеризованы как ядро семантического поля, отражающего конфликт любви и ненависти: haine (ненависть) - amour (любовь); aimer (любить) - détester (ненавидеть), aimer (любить) - haїr (ненавидеть), n'aimer (не любить) - ne détester (не ненавидеть). К ядру семантического поля также были отнесены стилистические антонимы, которые были выявлены в каждой из частей трилогии. Данную группу антонимов характеризует их употребление автором вне антонимической пары, т. е. данный тип антонимов используется автором для выражения индивидуального авторского концепта, что позволило охарактеризовать подобные антонимы как авторские: détester (ненавидеть), aimer (любить), hä̈ (ненавидеть), amour (любовь), haine (ненависть).

Далее была отмечена группа антонимов, трактуемая нами как периферийная группа, содержащая лексемы, вербализующие противопоставляемые концепты, которые являются индивидуально-авторскими. Данные лексемы вступают в антонимические отношения исключительно в контексте. Например, такие лексемы, характеризующие проявления ненависти, как siffler (шипеть), fourner de vis (закручивать гайки), coup de talon (удар каблуком), goût de malheur (вкус несчастья) и т. д. Проявление любви и ее описание представлены следующими лексемами: chocolat (шоколад), la main sur mon épaule (рука на моем плече), nulle parade (ничего показного) и т. д.

Нами были исследованы 94 лексемы, вербализующие авторский концепт «любовь», и 82 лексемы, вербализующие концепт «ненависть». Первая часть трилогии содержит 17 лексем, вербализующих концепт любви, и 54 лексемы, характеризующие концепт «ненависть». Вторая часть - 63 лексемы, вербализующие концепт любви, и 18 лексем, соответствующих концепту ненависти. Третья часть трилогии содержит 14 и 10 лексем соответственно.

Первая часть трилогии, помимо ненависти, царящей в семейном замке Резо, демонстрирует политику лишений и наказаний мадам Резо. Мать строго следит за выполнением всех ее приказов и выдуманных ею правил, наказывая за малейшие провинности и протесты. Подобная своеобразная тюрьма, где главным надзирателем выступает мать, сковывает главного героя, провоцируя его не только на проявление ненависти, но и на борьбу за собственную свободу. Так рождается конфликт, в котором противоборствующими сторонами оказываются снова мать и сын, где мать выступает в роли «носителя» несвободы, а сын, напротив, является «хранителем» идеи свободы и свержения тирана.

\section{Антитеза «любовь - ненависть»}

Подводя итог изучению средств вербализации антитезы «любовь - ненависть», важно отметить следующие особенности выражения данного конфликта. Во-первых, необходимо подчеркнуть динамику развития конфликта, отраженную в частотности и в специфике выбора лексических средств: высшая точка конфликта отмечена высокочастотной лексикой, описывающей ненависть, и, напротив, малочастотной лексикой, относящейся к проявлению любви. Во второй части трилогии мы наблюдаем тенденцию к повышению частотности лексики, вербализующей концепт «любовь»: touchante à souhait (трогательная до слез), trotter (носиться), main sur mon épaule (рука на моем плече), brille une légère alliance (сверкает тонкое обручальное кольцо), force (сила), madone blanche (белая мадонна), fleur (цветок), miel (мед), collection de joies (коллекция радостей) и т. д. Так, подводя промежуточный итог, мы делаем вывод о том, что лексические средства вербализации антитезы «любовь - ненависть» представлены в тексте в динамике.

Во-вторых, в процессе исследования текста были выделены многочисленные средства репрезентации конфликта «любовь - ненависть». Средства, используемые автором при демонстрации конфликта через прием внешней фокализации, являются как языковыми, так и контекстуальными антонимами: baiser (целовать) - gifler (давать пощечину); effusions (ласки) - représailles (репрессии); accobler (угнетать) - aider (помогать); ne détester (не ненавидеть) - n'aimer (не любить) и т. д. Напротив, средства демонстрации антитезы с точки зрения главного героя оказываются исключительно контекстуальными антонимами, что может быть объяснено субъективным восприятием действительности Жаном Резо: idéniable entente (cемейное согласие) - aversion (враждебность); soleil (солнце) - nuit (ночь); effusions (ласки) - coup de fourchette (удар вилкой); vivre côte à côte (жить бок о бок) - s'acharner (настраивать против).

\section{Антитеза «свобода - несвобода»}

Изучаемая антитеза «свобода - несвобода» также представлена исключительно стилистическими антонимами. В процессе исследования лексема liberté (свобода), наличие которой прослеживается в первой и второй частях трилогии, была определена как ядерная лексема семантического поля конфликта «свобода - несвобода». Важно подчеркнуть, что лексика, характеризующая борьбу за свободу главного героя, не так частотна, как лексика, верблизующая конфликт любви и ненависти. Однако, изучая антитезу «свобода - несвобода» на предмет наличия лексики, характеризующей ее с позиции субъективного восприятия свободы Жаном Резо, мы обнаружили ее более высо- 
кую частотность. Восприятие Жаном Резо концепта «свобода» показано автором с помощью приема внутренней фокализации. Главный герой видит проявление собственной свободы в любых поступках, отражающих его протест против матери: regarder fixement (смотреть в упор), s'affirmer (самоутверждаться), contredir (отрицать), vin (вино), adolescence (взросление) и т. д.

Итак, в первой части трилогии было выделено 7 лексем, вербализующих концепт «свобода», и 13 лексем, характеризующих концепт «несвобода». Вторая часть трилогии содержит 1 лексему, описывающую концепт «свобода», и 1 лексему, относящуюся к концепту «несвобода». Третья часть трилогии содержит 18 и 1 лексему соответственно. Из этого следует, что лексика, вербализующая антонимические отношения, выполняет не только функцию выражения конфликтов, но и демонстрирует динамику развития противостояния. Конфликт таких противоположных явлений, как разрушение и созидание, отражает естественное течение времени, которое оказывает влияние на сюжет и на судьбы персонажей: сменяются люди в жизни Жана Резо, сменяются поколения, и на смену устаревшему приходит новое. Однако в трилогии мы отмечаем не только власть судьбы над персонажами романа. Мадам Резо оказывается символом разрушения - она собственными руками рушит создаваемые Жаном Резо отношения.

Антитеза «свобода - несвобода» продемонстрирована наиболее ярко в первой части трилогии, причем большая концентрация лексических средств выражения конфликта отмечена при рассмотрении противопоставления с точки зрения главного героя, что может быть обусловлено доминированием концепта «несвобода» и отсутствием возможности у главного героя действовать открыто. Во второй части трилогии также отмечается повышенная частотность лексики, относящейся к субъективному восприятию конфликта Жаном Резо, который может быть объяснен особым взглядом главного героя на собственную свободу.

\section{Антитеза «разрушение - созидание»}

Интересующая нас антитеза «разрушение - созидание» представлена также только стилистическими антонимами. Ядром семантического поля, включающего антитезы «разрушение - созидание», стали такие авторские пары антонимов, как decliner-montre (приходить в упадок - подниматься), aller - arriver (уходить - приходить), se marier -s'enterrer (жениться - хоронить), jeunes - vieux (молодой - старый). Также были отобраны непарные стилистические антонимы в количестве 61, вступающие в отношения противопоставления и относящиеся к периферии стилистического поля данного конфликта: décliner (идти к упадку), s'effondre (рушиться), respirer seul (дышать в одиночестве), vielles familles (старинные семейства) - nouvelle dénération (новое поколение).

Важно отметить, что старое поколение семьи Резо не созидает. Главным создателем является Жан Резо. Именно он создает сопротивление против матери, именно он выстраивает дружеские и любовные отношения и, наконец, именно он создает семью, совершенно отличную от Резо, лишенную изъянов, присущих семье его детства. Так, в первой части трилогии Жан Резо создал: Déclaration des droits (Декларация прав), cartel des Gosses (картель мальчишек). Выбор лексики обусловлен протестом, вынудившим главного героя создать подобие организации по защите прав и ее устава. Во второй и третьей части трилогии мы прослеживаем эволюцию повзрослевшего Жана Резо: enfant (ребенок), fils (сын), mariage (брак), nouvelle dénération (новое поколение).

Результатом анализа трилогии «Змея в кулаке» с точки зрения авторского приема внутренней фокализации стало формирование группы стилистических антонимов, вербализующих указанные ранее конфликты. Проанализированные лексемы также были расположены на перифериях семантических полей антитез, к которым они относятся. Так, антитеза «любовь - ненависть» представлена 172 лексемами, находящимися в отношениях противопоставления, антитеза «свобода - несвобода» - 113 лексемами. Антитеза «разрушение - созидание» с позиции приема внутренней фокализации не представлена.

Необходимо отметить, что изучение трилогии «Змея в кулаке» с точки зрения авторского приема внутренней фокализации определило факт отсутствия лексических средств вербализации антонимических отношений, выражающих противопоставление «созидание - разрушение». Данное явление объясняется тем, что автор наглядно демонстрирует процесс смены поколений и разрушения поместья семьи Резо, который только описывается главным героем и трактуется им объективно. Разрушение находит свое выражение в смерти родственников главного героя, в крушении устаревших уставов и исчезновении отслуживших слоев общества. Созидание противопоставляется разрушению благодаря таким явлениям, как рождение детей и создание семей нового порядка.

Полученные данные позволили нам сделать следующие выводы.

Во-первых, изучение трилогии Э. Базена «Семья Резо» с целью выявления лексических средств вербализации антонимических отношений, имплицируемых антитезой, показало, что антонимические отношения в тексте представлены контекстуальными и лингвистическими антонимами. Употребление автором выявленных антонимов в рамках данного исследования трактуется как авторское средство выраже- 
ния, подчеркивающее основные конфликты трилогии, динамику их развития. Так, были выявлены три основных противостояния трилогии: «любовь - ненависть», «свобода - несвобода», «разрушение - созидание», входящие в состав общей антитезы «герой - внешний мир», и лексические средства их выражения, представленные как контекстуальными, так и лингвистическими антонимами, которые, относясь к противопоставляемым концептам, вступают не только в антонимические отношения, но и в отношения взаимодействия.

Лексическая антонимия обнаруживается в основном при исследовании противопоставлений с точки зрения авторского приема внешней фокализации, в то время как контекстуальная антонимия оказывается признаком демонстрации конфликтов через субъективное мнение главного героя.

Следовательно, представляя конфликт с различных точек зрения, антонимические отношения являются взаимосвязанными. Они позволяют отследить конфликт, начиная со стадии его зарождения и заканчивая его исчезновением. Подобная демонстрация конфликтов трилогии создает акцент на конфликтной направленности сюжета, превращая контекстуальную и лингвистическую антонимию в основное средство выражения авторского концепта трилогии «Семья Резо».

Во-вторых, наличие антонимических отношений отмечено на протяжении всей трилогии, так как именно наличие противопоставления оказывается основополагающим выражением авторского концепта.

Во-третьих, лексика, вербализующая антонимические отношения, выполняет не только функцию выражения конфликтов, но и демонстрирует динамику развития противостояния. Так, количество выявленных лексических средств вербализации антитезы «любовь - ненависть» позволяет судить о течении конфликта, выделить его высшую точку в первой части трилогии и низшую в третьей. Конфликт «свобода - несвобода» также обладает нисходящей динамикой. Мы отмечаем большую концентрацию лексических средств вербализации противопоставления в первой части трилогии и их отсутствие в третьей, что означает также отсутствие антитезы. Противопоставление концептов «разрушение» и «созидание», напротив, обладает восходящей динамикой, так как приобретает наибольшее количество средств вербализации в третьей части трилогии.

В-четвертых, авторский прием внутренней фокализации представляет изучаемые антитезы с точки зрения главного героя, что сопровождается наличием только стилистических антонимов в качестве средств вербализации конфликта. Некоторые лексические средства вербализации антонимических отношений также выполняют стилистическую функцию, т. е. подчинены индивидуально-авторскому концепту. Более того, частотность лексики, вербализующей антонимические отношения трилогии через призму восприятия героя, превосходит частотность лексики, вербализующей идентичные конфликты с точки зрения приема внешней фокализации. Подобное явление объясняется спецификой индивидуально-авторского подхода к описанию личности главного героя, а также спецификой психологизма творчества Э. Базена.

Подводя итог исследованию, отметим, что антонимические отношения в трилогии Э. Базена «Змея в кулаке» могут быть вербализованы как ядерными, исключительно лингвистическими антонимами, так и периферийными, исключительно стилистическими средствами, выражающими антонимические отношения изученной трилогии.

\section{ЛИТЕРАТУРА}

1. Карпенко С. М. Анализ межтекстовых ассоциативно-смысловых полей в аспекте идиостиля (на материале поэзии Н. С. Гумилева) // Коммуникативно-прагматические аспекты слова в художественном тексте. Томск : Изд-во ЦНТИ, 2000. С. 23-34.

2. Красавский Н. А. Метафорическая репрезентация концепта «одиночество» в романе Германа Гессе «Степной волк» // Рефлексии. Журнал по философской антропологии. 2010. С. 118-133.

3. Бахтин М. М. Эстетика словесного творчества. М. : Искусство, 1986. 300 с.

4. Кубрякова E. С. Краткий словарь когнитивных терминов. М. : Филол. ф-т МГУ им. М. В. Ломоносова, 1997. $245 \mathrm{c}$.

5. Полянчук О. Б., Свиридова Е. И. Словообразовательные средства реализации концепта-оппозиции «герой - окружающий мир» в романе Э. Базена «Змея в кулаке» // Когнитивные исследования языка. Тамбов : ПРИНТ-СЕРВИС, 2018. С. 317-322.

6. Манджиева С. В. Ключевые концепты в рассказах О. Генри : автореф. дис. ... канд. филол. наук. Волгоград : Перемена, 2010. 23 с.

7. Барт Р. S/Z / М. : Культура ; Ad Marginem, 1994. $303 \mathrm{c}$.

8. Bally Ch. Traité de stylistique frainçaise. Paris : Genève, 1951. $332 \mathrm{p}$.

9. Robrieux J.-J. Rhétorique et argumentation. Paris : Edition NATHAN/HER, 2000. 262 p.

10. Полянчук О. Б. Когнитивные причины закономерностей семантической деривации производных слов (на материале французского языка) // Вестник Воронеж. гос. ун-та. Сер.: Лингвистика и межкультурная коммуникация. 2005. № 2. С. 47-50.

11. Полянчук О. Б. Когнитивные основы перевода лексических единиц, репрезентированных комплексным знаком // Социокультурные проблемы перевода : сб. науч. тр. : в 2 ч. / Воронеж. гос. ун-т. Воронеж, 2006. Вып. 7, ч. 2. С. 195-202. 
12. Гончарова E. А. Интерпретация художественного текста. М. : Просвещение, 1989. 208 с.

13. Литвиненко Н. А. Французский исторический роман первой половины XIX века // Эволюция жанра : учеб. пособие. М. : УРАО, 1999. 163 с.

14. Женетт Ж. Фигуры. М. : Изд-во им. Сабашниковых, 1998. 944 с.

15. Шмид В. Нарратология. М. : Языки славянской культуры, 2003. 312 с.

16. Успенский Б. А. Поэтика композиции. СПб. : Азбука, 2000. 352 с.

\section{ИСТОЧНИКИ}

1. Bazin $H$. Vipère au poing. P. : Éditions Le Livre de Poche, 1972. 186 p.

2. Bazin H. Cri de la chouette. P. : Grasset, 1973. 297 p.

3. Bazin H. La mort du petit cheval. P. : Éditions Le Livre de Poche, 1972. 224 p.

\section{REFERENCES}

1. Karpenko S. M. Analiz mezhtekstovyh associativno-smyslovyh polej $\mathrm{v}$ aspekte idiostilya (na materiale poezii N. S. Gumileva). In Kommunikativno-pragmaticheskie aspekty slova $v$ hudozhestvennom tekste. Tomsk: Izd-vo CNTI, 2000. Pp. 23-34.

2. Krasavskij N. A. Metaforicheskaya reprezentaciya koncepta «odinochestvo» v romane Germana Gesse «Stepnoj volk». In Refleksii. Zhurnal po filosofskoj antropologii, 2010. Pp. 118-133.

3. Bahtin M. M. Estetika slovesnogo tvorchestva. Moskva: Iskusstvo, 1986. 300 p.

4. Kubryakova E. S. Kratkij slovar'kognitivnyh terminov. Moscow: Filol. f-t MGU im. M. V. Lomonosova, 1997. 245 p.

5. Polyanchuk O. B., Sviridova E. I. Slovoobrazovatel'nye sredstva realizacii koncepta-oppozicii «geroj-okruzhayushchij mir» v romane E. Bazena «Zmeya v kulake». In Kognitivnye issledovaniya yazyka. Tambov: PRINT-SERVIS, 2018. Pp. 317-322.

Воронежский государственный университет

Полянчук О. Б., доктор филологических наук, профессор кафедры франиузской филологии

E-mail: bollona@mail.ru

Свиридова Е. И., аспирант кафедры франиузской филологии

E-mail: Zhenia.korypaeva@yandex.ru

Поступила в редакичю 23 ноября 2019 г.

Принята к публикачии 27 декабря 2019 г.

\section{Для цичтирования:}

Полянчук О. Б., Свиридова Е. И. Лексические средства вербализации антонимических отношений в трилогии Эрве Базена «Змея в кулаке» // Вестник Воронежского государственного университета. Серия: Лингвистика и межкультурная коммуникация. 2020. № 1 . C. 103-111. DOI: https://doi.org/10.17308/lic.2020.1/2738
6. Mandzhieva S. V. Klyuchevye koncepty v rasskazah O. Genri: avtoref. diss. ... kand. filol. nauk. Volgograd: Peremena, 2010. 23 p.

7. Bart R. S/Z. Moscow: Kul'tura; Ad Marginem, 1994. 303 p.

8. Bally Ch. Traité de stylistique frainçaise. Paris: Genève, 1951. $332 \mathrm{p}$

9. Robrieux, J.-J. Rhétorique et argumentation. Paris: Edition NATHAN/HER, 2000. 262 p.

10. Polyanchuk O. B. Kognitivnye prichiny zakonomernostej semanticheskoj derivacii proizvodnyh slov (na materiale francuzskogo yazyka). In Vestnik Voronezh. gos. un-ta. Ser.: Lingvistika i mezhkul'turnaya kommunikaciya. 2005. № 2. Pp. 47-50.

11. Polyanchuk O. B. Kognitivnye osnovy perevoda leksicheskih edinic, reprezentirovannyh kompleksnym znakom. In Sociokul 'turnye problemy perevoda: sb. nauch. tr.: v 2 ch. / Voronezh, gos. un-t. Voronezh, 2006. Vyp. 7, ch. 2. Pp. 195-202.

12. Goncharova E. A. Interpretaciya khudozhestvennogo teksta. Moscow: Prosveshchenie, 1989. 208 p.

13. Litvinenko N. A. Francuzskij istoricheskij roman pervoj poloviny XIX veka. In Evolyuciya zhanra: Uchebnoe posobie. Moscow: Izdatel'stvo URAO, 1999. 163 p.

14. Zhenett Z. Figury. Moscow: Izd-vo im. Sabashnikovyh, $1998.944 \mathrm{p}$.

15. Shmid B. Narratologiya. Moscow: Yazyki slavyanskoj kul'tury, 2003. 312 p.

16. Uspenskij B. A. Poetika kompozicii. SPb.: Azbuka, 2000. 352 p.

\section{SOURCES}

1. Bazin H. Vipère au poing. P.: Éditions Le Livre de Poche, 1972. 186 p.

2. Bazin H. Cri de la chouette/. P.: Grasset, 1973. 297 p.

3. Bazin H. La mort du petit cheval. P.: Éditions Le Livre de Poche, 1972. 224 p.

Voronezh State University

Polyanchuk O. B., Doctor of Philology, Professor of the French Philology Department

E-mail:bollona@mail.ru

Sviridova E. I., Post-graduate Student of the French Philology Department

E-mail: Zhenia.korypaeva@yandex.ru

Received: 23 November 2019

Accepted: 27 December 2019

\section{For citation:}

Polyanchuk O. B., Sviridova E. I. Lexical means of antonymic relations verbalization in trylogy of Hervé Bazin's novel «Vipère au poing». Proceedings of Voronezh State University. Series: Linguistics and Intercultural Communication. 2020. No. 1. Pp. 103-111. DOI: https:// doi.org/10.17308/lic.2020.1/2738 